\title{
Nitrogen fertilization impact on agronomic traits of maize hybrids released at different decades ${ }^{(1)}$
}

Luís Sangoi(2), Márcio Ender ${ }^{(2)}$, Altamir Frederico Guidolin ${ }^{(2)}$, Milton Luiz de Almeida( ${ }^{(3)}$ and Valmor Antônio Konflanz ${ }^{(3)}$

\begin{abstract}
Genetic selection of maize hybrids is often conducted using high $\mathrm{N}$ rates during the breeding cycle. This procedure may either lead to the release of genotypes that present nitrogen luxury consumption or require a stronger $\mathrm{N}$ input to accomplish their yield potential. This work was carried out to evaluate the effects of $\mathrm{N}$ rates on grain yield and $\mathrm{N}$ use efficiency of hybrids cultivated in different decades in Southern Brazil. The trial was performed in Lages, Santa Catarina State. A split plot design was used. Hybrids Ag 12, Ag 28, Ag 303 and Ag 9012, released during the 60's, 70's, 80's and 90 's, respectively, were evaluated in the main plots. Nitrogen rates equivalent to $0,50,100$ and $200 \mathrm{~kg} \mathrm{ha}^{-1}$ were side-dressed in the split-plots when each hybrid had six fully expanded leaves. Modern-day hybrid Ag 9012 had higher grain yield than hybrids of earlier eras, regardless of $\mathrm{N}$ rates. Under high doses of $\mathrm{N}$, the older hybrids Ag 12 and Ag 28 took up more $\mathrm{N}$ and presented higher values of shoot dry matter at flowering than Ag 9012. Nonetheless, they set less grains per ear which contributed to decrease their grain yield and $\mathrm{N}$ use efficiency.
\end{abstract}

Index terms: Zea mays, hybrids, absorption, crop yield.

\section{Impacto da fertilização nitrogenada sobre características agronômicas de híbridos de milho lançados em diferentes décadas}

\begin{abstract}
Resumo - Novos híbridos de milho são normalmente desenvolvidos utilizando-se altas doses de N durante o ciclo de seleção. Isto pode favorecer o lançamento de genótipos que apresentem consumo de luxo de $\mathrm{N}$ ou requeiram altas doses deste nutriente para expressarem o seu potencial produtivo. Este trabalho foi conduzido para avaliar os efeitos de doses de $\mathrm{N}$ sobre o rendimento de grãos e eficiência de uso do $\mathrm{N}$ de híbridos cultivados em diferentes épocas no sul do Brasil. O ensaio foi conduzido em Lages, Santa Catarina. Os híbridos Ag 12, Ag 28, Ag 303 e Ag 9012, lançados comercialmente nas décadas de 60, 70, 80 e 90, respectivamente, foram avaliados na parcela principal. Doses de $\mathrm{N}$ de 0,50 , 100 e $200 \mathrm{~kg} \mathrm{ha}^{-1}$ foram aplicadas em cobertura nas subparcelas. O híbrido moderno Ag 9012 expressou maior rendimento de grãos do que os demais híbridos, independentemente da dose de $\mathrm{N}$ testada. Quando foram utilizadas altas doses de $\mathrm{N}$, os híbridos antigos Ag 12 e Ag 28 absorveram mais $\mathrm{N} \mathrm{e}$ concentraram mais matéria seca na parte aérea durante o florescimento. No entanto, produziram menor número de grãos por espiga, menor rendimento de grãos e eficiência de uso do nitrogênio.
\end{abstract}

Termos para indexação: Zea mays, híbridos, absorção, rendimento de cultura.

\section{Introduction}

Maize is one of the grasses that present greater $\mathrm{N}$ requirements to reach high grain yields, removing from the soil between 20 and $25 \mathrm{~kg}$ of $\mathrm{N}$ per ton of

\footnotetext{
(1) Accepted for publication on August 23, 2000.

(2) Universidade do Estado de Santa Catarina (UDESC), Dep. de Fitotecnia, Caixa Postal 281, CEP 88520-000 Lages, SC E-mail: a21s@cav.udesc.br, ender@cav.udesc.br, guidolin@cav.udesc.br

(3)UDESC, Dep. de Fitotecnia. CNPq scholar. E-mail a2mla@cav.udesc.br, valmorkonflanz@bol.com.br
}

grain produced (Muzilli \& Oliveira, 1992). Nitrogen plays a pivotal role in several physiological processes inside the plant. It is fundamental to establish the plant's photosynthetic capacity (Hageman \& Below, 1984); it prolongs the effective leaf area duration, delaying senescence (Earl \& Tollenaar, 1997); it is important for ear and kernel initiation, contributing to define maize sink capacity (Tollenaar et al., 1994); and it helps to maintain functional kernels throughout grain filling, influencing the number of developed kernels and kernel final size (Huber et al., 1994; Jones et al., 1996). 
The effect of $\mathrm{N}$ availability on important maize agronomic traits has been examined by a number of workers (McCullough et al., 1994b; Sangoi \& Almeida, 1994; Ernani et al., 1996). Nitrogen limiting conditions produce several restrictions to plant development, delaying silking (Russel, 1991), decreasing pre-anthesis crop growth rate (McCullough et al., 1994a), dwindling leaf area index at flowering and accelerating leaf senescence rates throughout the life cycle (Wolfe et al., 1988).

Maize grain yield potential has increased dramatically during the last 50 years especially in temperate regions of the world (Russel, 1991; Tollenaar et al., 1994). This yield enhancement can be largely attributed to the release of genetic superior hybrids, higher plant densities, increased use of chemical fertilizers, reduction of row spacing, improved cultural practices, better weed and pest control (Carlone \& Russel, 1987; Dwyer et al., 1991; Tollenaar, 1991).

The level of soil fertility has not been used directly as a selection tool in the development and evaluation of maize inbred lines (Russel, 1991). In addition to that, genetic selection is often conducted at high level of $\mathrm{N}$ application in order to eliminate $\mathrm{N}$ as a restrictive variable during the selection process (Kamprath et al., 1982). This methodology may mitigate differences among genotypes in terms of $\mathrm{N}$ use efficiency to accomplish higher yields. Moreover, it may contribute to the release of hybrids which have greater yield potential but also require a stronger $\mathrm{N}$ input to express their agronomic superiority. The use of high $\mathrm{N}$ levels during hybrid development may also lead to the selection of genotypes that have luxury consumption of N (Carlone \& Russel, 1987).

Information currently available in the literature has not considered possible parallel changes in the $\mathrm{N}$ stress tolerance and $\mathrm{N}$ use efficiency of Brazilian hybrids representing different decades of direct selection for increased grain yield. There is no report of a trial comparing under similar management conditions the response of hybrids grown in the last forty years in Southern Brazil to different $\mathrm{N}$ rates.

This work was carried out to evaluate the effects of $\mathrm{N}$ rates on grain yield, $\mathrm{N}$ use efficiency and other agronomic traits of hybrids cultivated in different decades in Southern Brazil.

\section{Material and Methods}

The experiment was carried out in the city of Lages, SC, Brazil, located at $27^{\circ} 52^{\prime}$ latitude South and $50^{\circ} 18^{\prime}$ longitude West. The climate of the region is classified by Köppen as $\mathrm{Cfb}$, presenting mild summers, cold winters and adequate rainfall during the whole year.

Soil study site was an Oxisol (Hapludox). A chemical analysis performed one month before installing the trial indicated the following soil characteristics: organic matter content, $40 \mathrm{~g} \mathrm{~kg}^{-1}$; clay content, $470 \mathrm{~g} \mathrm{~kg}^{-1}$; $\mathrm{P}$, $25 \mathrm{mg} \mathrm{L}^{-1} ; \mathrm{K}, 280 \mathrm{mg} \mathrm{L}^{-1}$; water pH 5.9; $\mathrm{Al}, 0.0 \mathrm{me} \mathrm{dL}^{-1}$; $\mathrm{Ca}, 10 \mathrm{me} \mathrm{dL}^{-1}, \mathrm{Mg}, 2.5 \mathrm{me} \mathrm{dL}^{-1}$.

The trial was designed as a factorial combination of two factors: hybrids and $\mathrm{N}$ rates. The experimental design was a split plot with the main plots arranged in randomized complete blocks. Each treatment was replicated four times. The double-cross hybrids Ag 12, Ag 28, Ag 303 and the single-cross hybrid Ag 9012, which were cultivated during the 60's, 70's, 80's and 90's, respectively, were evaluated in the main plots. Each hybrid was highly successful and widely grown throughout Southern Brazil for several years after its release. All hybrids were bred and released by Agroceres S.A. Four N rates, 0, 50, 100 and $200 \mathrm{~kg} \mathrm{ha}^{-1}$ were side-dressed in the split plots. These $\mathrm{N}$ rates are equivalent to $0,1 / 2,1$ and 2 times the prescribed doses for maize growers who aim to produce more than $6,000 \mathrm{~kg} \mathrm{ha}^{-1}$ of grains in soils with an organic matter content ranging from 35 and $45 \mathrm{~g} \mathrm{~kg}^{-1}$ in Southern Brazil (Comissão de Fertilidade do Solo-RS/SC, 1995). Each split plot was constituted by four six meter rows.

A conventional tillage method was used to prepare the soil. During the planting day, $20 \mathrm{~kg}$ of N, $80 \mathrm{~kg}$ of P and $100 \mathrm{~kg}$ of K per hectare were applied. Phosphorus and K rates were defined considering the reposition values suggested by Comissão de Fertilidade do Solo-RS/SC (1995) in areas where the goal is accomplish grain yields higher than $6,000 \mathrm{~kg} \mathrm{ha}^{-1}$.

The experiment was hand-planted on October 30, 1998. A row spacing of $80 \mathrm{~cm}$ and a plant density of 75,000 plants per hectare were used. Three seeds were dropped per hill to assure the desired stand on each treatment. The space between two adjacent hills within each row was nearly $17 \mathrm{~cm}$. When plants were at the stage of V4 (Ritchie \& Hanway, 1993), thinning was performed to adjust the population to the desired level.

A combination of atrasine $\left(1,400 \mathrm{~g} \mathrm{ha}^{-1}\right.$ of a.i.) and metolachlor $\left(2,100 \mathrm{~g} \mathrm{ha}^{-1}\right.$ of a.i. $)$ was sprayed right after planting to control weeds prior to their emergence. Plots were also hand-hoed to suppress weed competition after their emergence as needed. At V3 and V7 the insecticide 
trichlorfom (400 $\mathrm{g} \mathrm{ha}^{-1}$ of a.i.) was used to control army worm (Spodoptera frugiperda) infestations.

Nitrogen doses were side-dressed to the soil using urea when plants had six fully expanded leaves (V6 stage, according to Ritchie \& Hanway, 1993). The ear leaves of five plants randomly chosen inside each split plot were collected at anthesis to estimate the plant's N status. Shoot $\mathrm{N}$ content was determined based upon $\mathrm{N}$ percentage of the ear leaf following method described by Tedesco et al. (1985). Plants used to estimate shoot $\mathrm{N}$ content were also harvested, dried and weighed. Nitrogen uptake for each hybrid at anthesis was determined multiplying ear leaf $\mathrm{N}$ content and shoot dry mass.

The interval between anthesis and silking was estimated by counting the difference in number of days required for $50 \%$ of the plants within each plot to present pollen shed and $90 \%$ of the plants to have visible silks.

The two central rows of each split plot were harvested, representing an area of $9.6 \mathrm{~m}^{2}$. Ears were dehusked, dried, shelled and weighed. Dry grain weight values were converted to an area of one hectare and adjusted to a standard moisture of $13 \%$. A sub-sample of 200 grains was taken and re-weighed. The value obtained was multiplied by 5 and converted to a moisture of $13 \%$ to express the weight of 1,000 grains. The number of grains per ear was estimated indirectly through the relationship between weight of 200 grains, weight of total number of kernels and number of ears harvested within each split plot.

An analysis of variance was performed. F values for main treatment effects and their interaction were considered significant at the $\mathrm{P}<0.05$ level. Whenever the $\mathrm{N}$ rate, hybrid or the interaction between them significantly influenced a variable, a regression analysis was performed and the linear and quadratic effects calculated. The equations that reached significance at the $\mathrm{P}<0.05$ level, provided the higher determination coefficients and better explained the biological behavior of each hybrid were chosen to summarize the information gathered for each variable. Hybrid's efficiency to convert the applied $\mathrm{N}$ into grain production was estimated considering the slopes calculated for genotypes with a linear response of grain yield to the range of $\mathrm{N}$ rates used in the trial. A t test at the $\mathrm{P}<0.05$ level was used to compare the slopes for variables that express a significant linear response. Nitrogen efficiency values were expressed in $\mathrm{kg}$ of grains per $\mathrm{kg}$ of side-dressed nitrogen

\section{Results and Discussion}

The oldest hybrid Ag 12 presented a quadratic response to the $\mathrm{N}$ rates tested in the trial, reaching its maximum grain yield when $176 \mathrm{~kg} \mathrm{ha}^{-1}$ of $\mathrm{N}$ were side-dressed at V6 (Figure 1). The other three hybrids enhanced their grain yield linearly when the $\mathrm{N}$ dose was raised from 0 to $200 \mathrm{~kg} \mathrm{ha}^{-1}$.

Each kilogram of $\mathrm{N}$ was converted into approximately $20 \mathrm{~kg}$ of additional grain production for $\mathrm{Ag} 303$ and Ag 9012. On the other hand, the impact of $\mathrm{N}$ fertilization on $\mathrm{Ag} 28$ grain yield was less pronounced (13 kg of extra grains per $\mathrm{kg}$ of applied $\mathrm{N}$ ). The $\mathrm{t}$ test showed that calculated slopes of $\mathrm{Ag} 303$ and Ag 9012 were significantly different from the slope of Ag 12, providing evidence that modern hybrids were more efficient to use the fertilizer to accomplish higher grain production.

When hybrids performance is compared in terms of percentage at each $\mathrm{N}$ rate, the modern hybrid Ag 9012 was 33\% more productive than the other genotypes when no $\mathrm{N}$ was side-dressed. This percent superiority diminished as $\mathrm{N}$ rates were increased reaching only $17 \%$ at the highest dose. In absolute values, modern hybrid Ag 9012 presented an yield edge over the older materials that ranged from 1,350 to $1,500 \mathrm{~kg} \mathrm{ha}^{-1}$, depending on the amount of $\mathrm{N}$ applied to the soil.

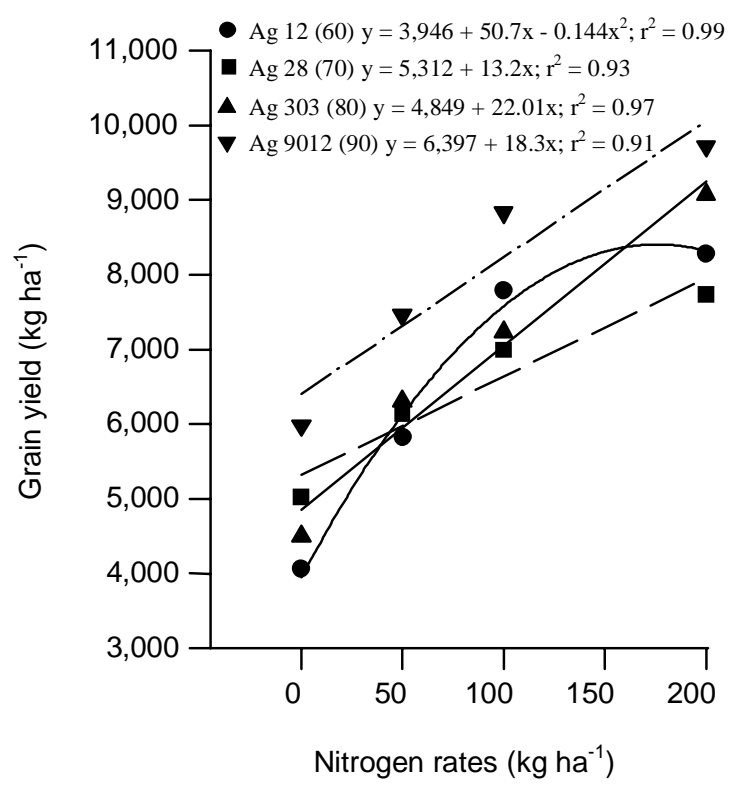

Figure 1. Effects of nitrogen rates on grain yield of maize hybrids released in different decades. Lages, SC, 1998/99. 
The impact of $\mathrm{N}$ on grain yield depicted in Figure 1 showed that hybrids cultivated in Southern Brazil during the last 40 years presented the same kind of behavior described by Castleberry et al. (1984), Carlone \& Russel (1987), Russel (1991) and Duvick (1994) for hybrids cultivated in the West US Corn Belt. Modern-day hybrid Ag 9012 had greater grain yield than did hybrids of earlier eras at all $\mathrm{N}$ rates evaluated in the trial. The improvement in $\mathrm{N}$ use efficiency is a part of the total genotype developed for higher grain yield. An important fact to emphasize is that the transition from double-cross hybrids to a high yielding, management responsive single-cross hybrid has not led to increase vulnerability in an unfavorable production situation, such as when no $\mathrm{N}$ was side-dressed. Therefore, the results of this experiment did not support the idea presented by Soule \& Piper (1992) that modern hybrids are less tolerant to stress and more demanding on high inputs than the cultivars used in the past. They also don't corroborate the claim that a shift to lower inputs would require abandonment of modern hybrids and the use of genotypes with a broader genetic variability (Bisognin et al., 1997).

Maize grain yield is primarily associated with variations in the number of mature kernels per ear which, in turn, depends on crop growth rates at silking (Otegui et al., 1995; Cantarero et al., 1999). The number of grains that reached maturity varied less pronouncedly with the increase in the amount of $\mathrm{N}$ side-dressed per area for the modern hybrid Ag 9012 (Figure 2). As an average, ears of $\mathrm{Ag} \mathrm{12,} \mathrm{Ag} 28$ and Ag 303 set 44\% more kernels when $\mathrm{N}$ application was raised from 0 to $200 \mathrm{~kg} \mathrm{ha}^{-1}$. Conversely, the difference in the number of mature kernels produced per ear by Ag 9012 at the lowest and highest $\mathrm{N}$ rates evaluated in the trial was only $11 \%$. Each modern hybrid's ear had 91 more grains than the ears of older materials when no $\mathrm{N}$ was side-dressed at V6.

Figure 3 depicts the evolution of the anthesissilking interval at the lowest and highest $\mathrm{N}$ doses tested in the trial regressed on year of hybrid introduction. Silk delay was consistently higher when no $\mathrm{N}$ was side-dressed. Maize is a species that presents a protandrous developmental pattern (Sangoi, 1996). This plant's characteristic is accentuated under adverse conditions such as nutritional deficiency, drought stress or high plant population (Sangoi \& Salvador, 1998b). Therefore, the lack of N side-dressing probably stimulated the plant's apical dominance, favoring tassel development, assuring pollen production and dispersion at the expense of ear and silk development

Regardless of $\mathrm{N}$ rate, the anthesis-silking interval was consistently smaller in newer hybrids than in the hybrids that preceded them (Figure 3). Excessive silk delay is a predictor of barrenness and the production of fewer kernels per ear (Duvick, 1994; Sangoi \& Salvador, 1998a). Modern hybrid Ag 9012 presented a better synchrony in the development of its male and female inflorescences. This agronomic feature allowed the newest hybrid to set more kernels per plant, contributing to its grain yield superiority over the older genotypes (Figures 2 and 3).

An important factor that may have affected hybrids' anthesis-silking interval and, consequently, impacted genotype response to $\mathrm{N}$ fertilization was the high plant population used on the trial $\left(75,000\right.$ plants $\left.\mathrm{ha}^{-1}\right)$. High plant population and

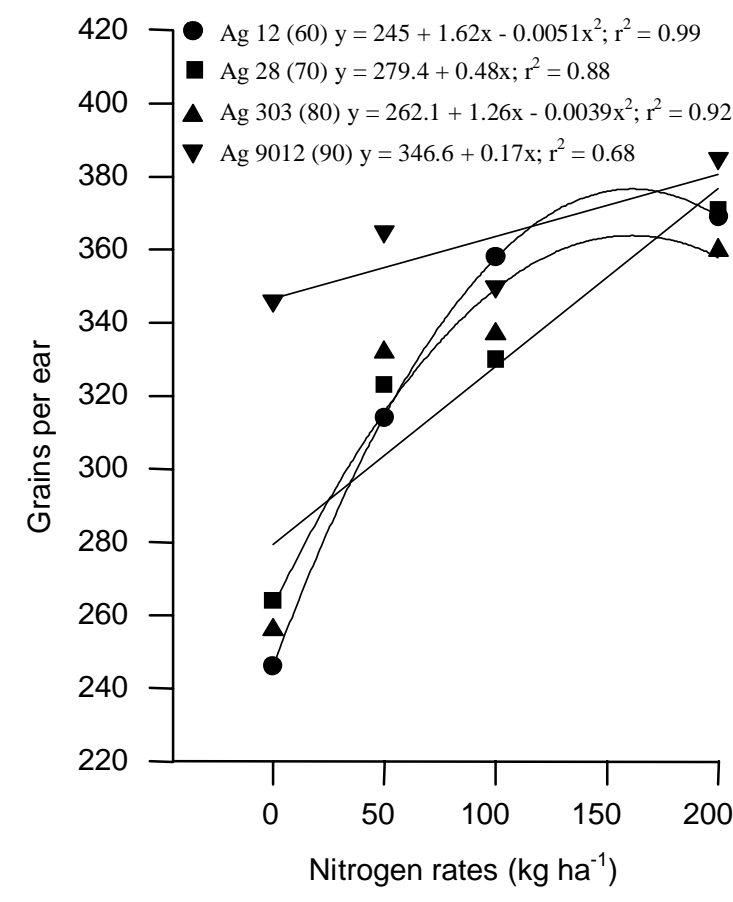

Figure 2. Effects of nitrogen rates on the number of grains per ear of maize hybrids released in different decades. Lages, SC, 1998/99. 
selfing have been useful management tools in breeding nurseries for eliciting maize tolerance to stressful environments (Edmeades et al., 1993). Selection against silk delay has been one of the most effective breeding methods to improve maize tolerance to environmental stresses (Russel, 1991). Poorly synchronized plants are automatically eliminated during the inbreed breeding process (Bolaños \& Edmeades, 1996). As a result of that, modern hybrids are better adapted to tolerate high plant densities which is a reflection of increased stress tolerance (Tollenaar et al., 1997). Therefore, 75,000 plants ha $^{-1}$ formed probably a stand that was above the optimum population density to maximize grain yield for the older genotypes. The use of higher than optimum plant population heightens interplant competition for light, water and nutrients (Olson \& Sanders, 1988). This may be detrimental to final yield because it stimulates apical dominance, enhances the anthesis-silking interval and decreases the number of kernels set per ear, leading to a lower conversion of $\mathrm{N}$ application into grain production.

Nitrogen content of the ear leaf at anthesis increased linearly with the enhancement in $\mathrm{N}$ rate for all hybrids used in this trial (Figure 4). However, the t test showed that the slopes of Hybrids Ag 12, Ag 28

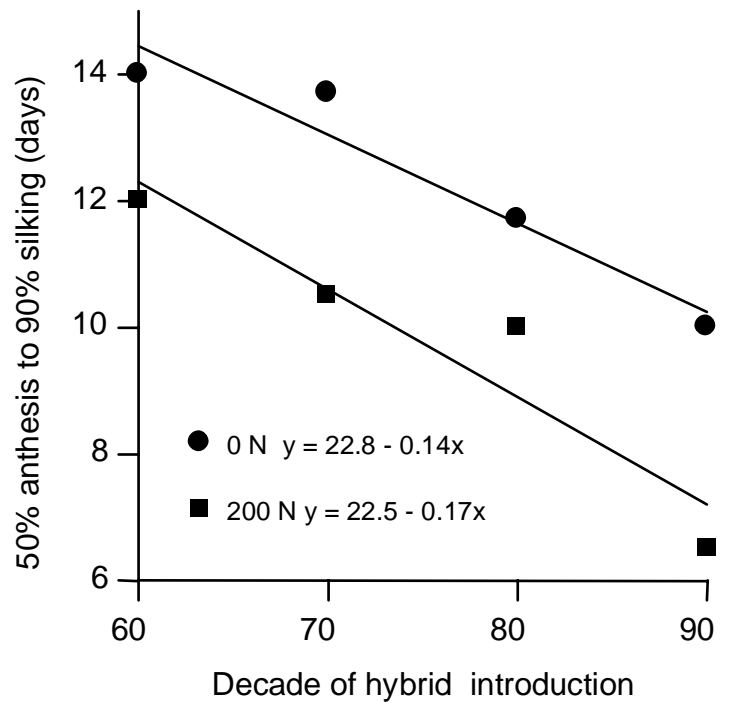

Figure 3. Effects of two nitrogen rates on the anthesissilking interval duration of maize hybrids released in different decades. Lages, SC, 1998/99. and Ag 303 were significantly higher than the calculated slope for Ag 9012. Each $100 \mathrm{~kg}$ of side-dressed $\mathrm{N}$ lifted $\mathrm{N}$ ear contend by nearly $0.4 \%$ as an average of the three older hybrids. This rate of $\mathrm{N}$ accumulation on the ear leaf was twice the value expressed by the modern hybrid Ag 9012.

The older hybrids shoot dry matter responded more drastically to the increase in $\mathrm{N}$ rates (Figure 5). The increase in $\mathrm{N}$ doses from 0 to $200 \mathrm{~kg}$ augmented maize shoot dry weight at flowering in 82, 37 and $42 \%$ for $\mathrm{Ag} \mathrm{12}, \mathrm{Ag} 28$, and $\mathrm{Ag} 303$, respectively. On the other hand, Ag 9012 expressed a shoot dry matter improvement of only $7 \%$ when $\mathrm{N}$ rate was risen from 0 to $200 \mathrm{~kg} \mathrm{ha}^{-1}$. When no $\mathrm{N}$ was side-dressed, hybrids had similar amounts of shoot dry matter at anthesis. Conversely, at the highest $\mathrm{N}$ rate Ag 9012 presented approximately $72 \%$ of the total above ground dry matter produced by the three other hybrids.

Hybrids did not differ in terms of $\mathrm{N}$ uptake at flowering when no side-dressing was performed (Figure 6). On the other hand, the hybrid introduced in

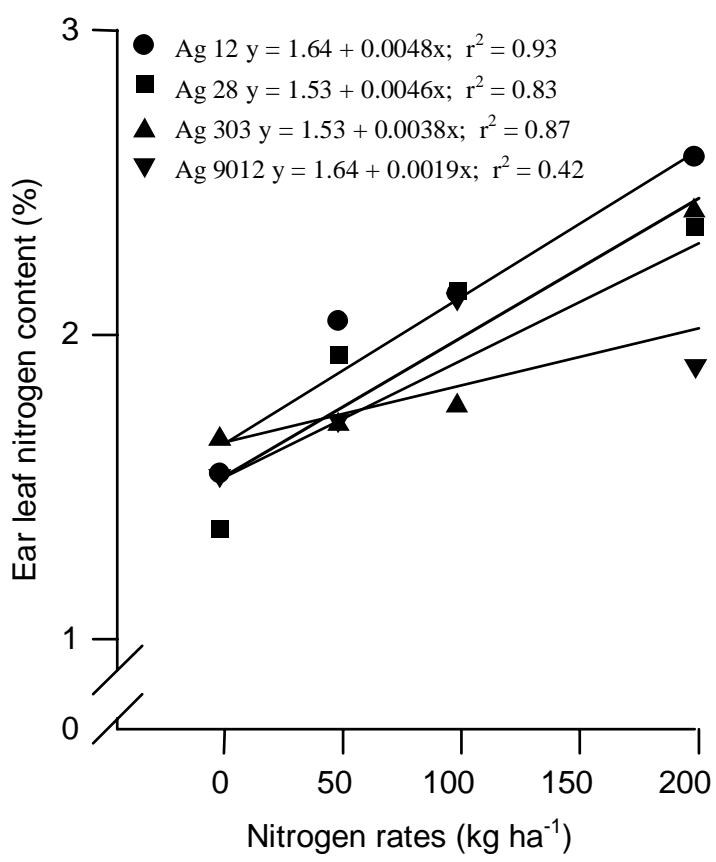

Figure 4. Effects of nitrogen rates on the ear leaf nitrogen content of maize hybrids released in different decades. Lages, SC, 1998/99.

Pesq. agropec. bras., Brasília, v. 36, n. 5, p. 757-764, maio 2001 
the 60's (Ag 12) was able to accumulate two times more $\mathrm{N}$ on its tissues than the hybrid released in the 90's (Ag 9012) at the highest fertilizer rate.

According to Huber et al. (1994), there are four general characteristics which determine the response of maize grain yield to $\mathrm{N}$ availability: root uptake; vegetative storage capacity; recycling efficiency from vegetative tissues to developing kernels; dynamics and strength of the kernel sink. Data presented on Figures 4, 5 and 6 show that $\mathrm{N}$ root uptake and $\mathrm{N}$ vegetative storage capacity until anthesis don't appear to be major causes for the older hybrids lower efficiency to convert mineral $\mathrm{N}$ in grain yield (Figure 1). The older hybrids used side-dressed $\mathrm{N}$ more effectively to increase plant height and thus enhance stover dry matter at anthesis (Figure 5). However, this potential $\mathrm{N}$ reservoir accumulated before flowering (Figure 6) was not strong enough to synchronize the development of male and female inflorescences and to set more kernels per plant (Figures 2 and 3 ).

A poor pollination in maize leads to sink suppression, increasing the source-sink ratio and resulting in the accumulation of carbohydrates in the stem

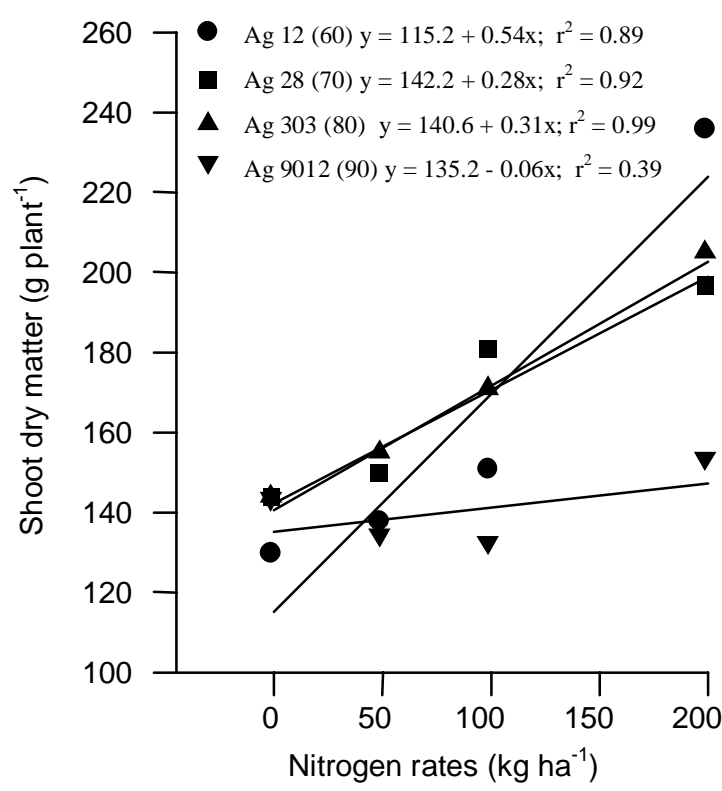

Figure 5. Effects of nitrogen rates on shoot dry matter at flowering of maize hybrids released in different decades. Lages, SC, 1998/99.
(Barnett \& Pearce, 1983; Rajcan \& Tollenaar, 1999b). In addition to that, a reduction in sink strength may reduce the leaf photosynthetic activity during grain filling, leading to an acceleration of leaf senescence (Tollenaar \& Daynard, 1982). With a weaker sink, the need and importance of recycling $\mathrm{N}$ from vegetative tissues to developing kernels is reduced.

The capacity of kernel $\mathrm{N}$ sink determine the yield potential of most commercial hybrids (Jones et al., 1996). This trait is highly linked to the length of $\mathrm{N}$ uptake during grain filling. High $\mathrm{N}$ responding hybrids require 40 to $50 \%$ of their total $\mathrm{N}$ after anthesis in contrast to the 10 to $20 \%$ additional $\mathrm{N}$ requirement for the low $\mathrm{N}$ responders (Huber et al., 1994). The ability of maize to maintain $\mathrm{N}$ uptake during grain filling may be related to the carbohydrate supply to the roots (Rajcan \& Tollenaar, 1999a). Since the older hybrids set a weaker sink during the onset of grain filling due to flower asynchrony, it is possible that the lack of sink strength led to a reduction of $\mathrm{N}$ demand within the plant decreasing $\mathrm{N}$ uptake by the roots after silking and diminishing $\mathrm{N}$ remobilization from the stover to the grains

There was a linear increase in the weight of 1,000 grains form the oldest to the most modern hybrid, considering the average of the four rates used in the trial (Figure 7). Since the final kernel weight

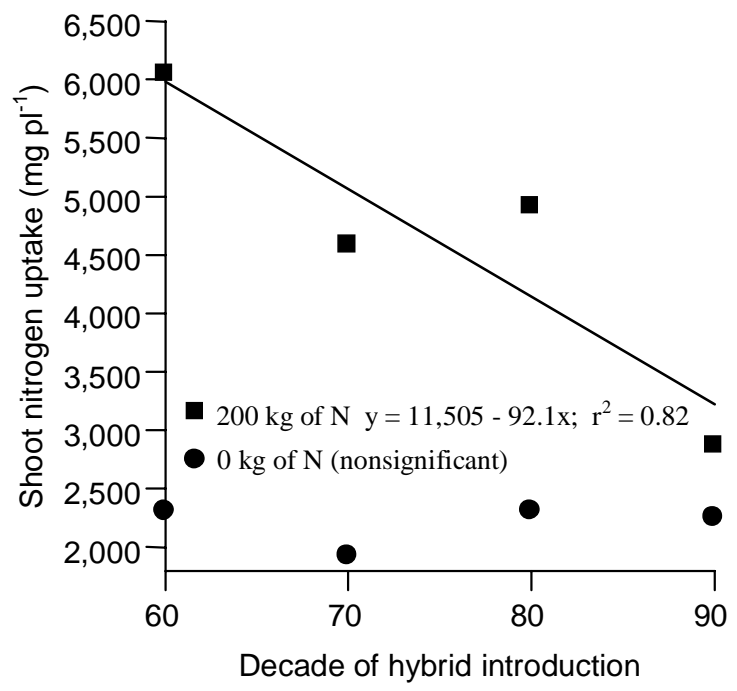

Figure 6. Effects of nitrogen rates on shoot nitrogen uptake at flowering of maize hybrids released in different decades. Lages, SC, 1998/99. 


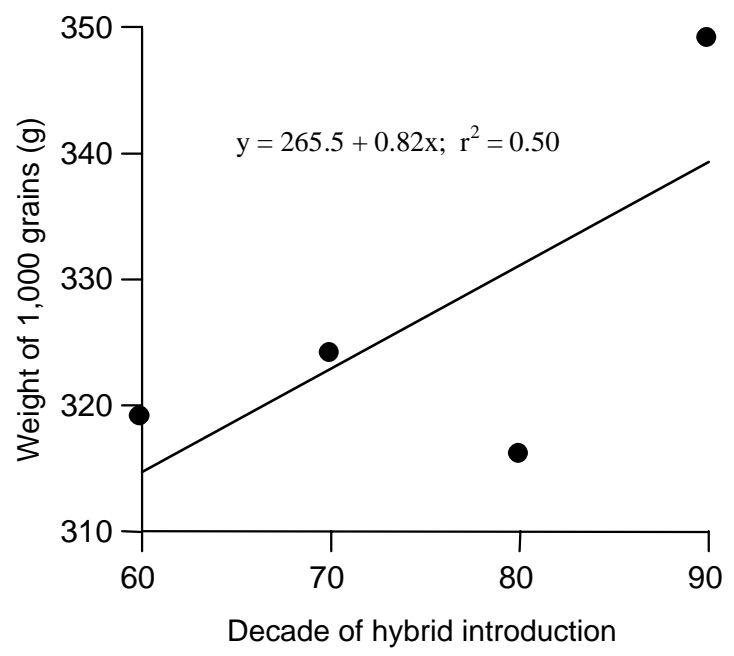

Figure 7. Weight of 1,000 grains of maize hybrids released in different decades, as an average of four nitrogen rates. Lages, SC, 1998/99.

depends largely on grain filling duration, data on Figure 7 may also be an indication that modern hybrids have a larger ability of either uptake $\mathrm{N}$ from the soil or remobilize it from vegetative tissues to grains after silking, delaying leaf senescence, prolonging the filling period and producing heavier grains. This physiological sequence of events have also been reported by Rajcan \& Tollenaar (1999a, 1999b) who ultimately attributed the higher $\mathrm{N}$ efficiency of modern hybrids to a better balanced source:sink ratio.

\section{Conclusions}

1. The modern-day hybrid Ag 9012 is more productive than the older hybrids, regardless of the amount of $\mathrm{N}$ side-dressed to the soil.

2. The lack of $\mathrm{N}$ side-dressing does not reduce modern-day hybrid grain yield more drastically than it does with hybrids used in the past.

3. Hybrids grown in the 60, 70 and 80's use high $\mathrm{N}$ rates more effectively to increase shoot dry matter at flowering than to accomplish great grain yields at harvesting.

\section{References}

BARNETT, K. H.; PEARCE, R. B. Source-sink ratio alteration and its effects on physiological parameters in maize. Crop Science, Madison, v. 23, n. 2, p. 294-299, Mar. 1983.

BISOGNIN, D. A.; CIPRANDI, O.; COIMBRA, J. L. M.; GUIDOLIN, A. F. Potencial de variedades de polinização aberta de milho em diferentes condições adversas de ambiente. Pesquisa Agropecuária Gaúcha, Porto Alegre, v. 3, n. 1, p. 29-34, out. 1997

BOLAÑOS, J.; EDMEADES, G. The importance of the anthesis-silking interval in breeding for drought tolerance in tropical maize. Field Crops Research, Amsterdam, v. 31, n. 2, p. 233-252, Feb. 1996.

CANTARERO, M. G.; CIRILO,A. G.; ANDRADE, F. H. Night temperature at silking affects kernel set in Maize. Crop Science, Madison, v. 39, n. 3, p. 703-710, May 1999.

CARLONE, M. R.; RUSSEL, W. A. Response to plant densities and nitrogen levels for four maize cultivars from different eras of breeding. Crop Science, Madison, v. 27, n. 2, p. 465-470, Mar. 1987

CASTLEBERRY, R. M.; CRUM, C. W.; CRULL, C. F. Genetic yield improvement of U.S. maize cultivars under varying fertility and climatic environments. Crop Science, Madison, v. 24, n. 1, p. 33-36, Jan. 1984.

COMISSÃO DE FERTILIDADE DO SOLO-RS/SC (Passo Fundo, RS). Recomendações de adubação e calagem para os Estados do Rio Grande do Sul e Santa Catarina. Passo Fundo : Sociedade Brasileira de Ciência do Solo/Embrapa-CNPT, 1995. 223 p.

DUVICK, D. N. Maize breeding: past, present and future. In: CONGRESSO NACIONAL DE MILHO E SORGO, 20., 1994, Goiânia. Anais... Goiânia : Embrapa-CNPMS, 1994. p. 170-179.

DWYER, L.; TOLLENAAR, M.; STEWART, D. W. Changes in plant density dependence of leaf photosynthesis of maize (Zea mays L.) hybrids, 1959 to 1988. Canadian Journal of Plant Science, Ottawa, v. 71, n. 1, p. 111, Jan. 1991.

EARL, H. J.; TOLLENAAR, M. Maize leaf absorptance of photosynthetically active radiation and its estimation using a chlorophyll meter. Crop Science, Madison, v. 37, n. 2, p. 436-440, Mar. 1997

EDMEADES, G. O.; BOLAÑOS, J.; LAFFITE, A. R. Progress in breeding for drought tolerance in maize. In: ANNUAL CORN \& SORGHUM RESEARCH CONFERENCE, 47., 1993, Chicago. Proceedings... Washington : American Seed Trade Association, 1993. p. 93-111.

ERNANI, P. R. E.; NASCIMENTO, J. A. L. do; FREITAS, E. G. Aumento do rendimento de grãos e de massa verde de milho para silagem pela aplicação de nitrogênio. Pesquisa Agropecuária Gaúcha, PortoAlegre, v. 2, n. 2, p. 201-205, jun. 1996. 
HAGEMAN, R. H.; BELOW, F. E. The role of nitrogen in the productivity of corn. In: ANNUAL CORN \& SORGHUM RESEARCH CONFERENCE, 39., 1984, Chicago. Proceedings... Washington : American Seed Trade Association, 1984. p. 145-155.

HUBER, D. M.; TSAI, C. Y.; STROMBERGER, J. A. Interaction of $\mathrm{K}$ with $\mathrm{N}$ and their influence on growth and yield potential of maize. In: ANNUAL CORNAND SORGHUM RESEARCH CONFERENCE, 48., 1994, Chicago. Proceedings... Washington : American Seed Company Association, 1994. p. 165-176.

JONES, R. J.; SCHREIBER, B. M. N.; ROESSLER, J. A. Kernel sink capacity in maize: genotypic and maternal regulation. Crop Science, Madison, v. 35, n. 2, p. 301-306, Mar. 1996

KAMPRATH, E. J.; MOLL, R. H.; RODRIGUEZ, N. Effects of nitrogen fertilization and recurrent selection on performance of hybrids populations of corn. Agronomy Journal, Madison, v. 74, n. 6, p. 955-958, Nov. 1982.

McCULLOUGH, D. E.; AGUILERA, A.; TOLLENAAR, M. N uptake, N partitioning, and photosynthetic N-use efficiency of an old and a new maize hybrid. Canadian Journal of Plant Science, Ottawa, v. 74, n. 2, p. 479-484, Mar. 1994a.

McCULLOUGH, D. E.; GIRARDIN, P.; MIHAJLOVIC M.; AGUILERA, A.; TOLLENAAR, M. Influence of N supply on the development and dry matter accumulation of an old and a new maize hybrid. Canadian Journal of Plant Science, Ottawa, v. 74, n. 2, p. 471-478, Mar. 1994b.

MUZILLI, O.; OLIVEIRA, E. L. Nutrição e adubação. In INSTITUTO AGRONÔMICO DO PARANÁ (Londrina, PR). O milho no Paraná. Londrina, 1992. p. 88-95. (IAPAR. Circular, 29).

OLSON, R. A.; SANDERS, D. H. Corn production. In: SPRAGUE, G. F.; DUDLEY, J. W. (Ed.). Corn and corn improvement. 3. ed. Madison : American Society of Agronomy, 1988. p. 675-698

OTEGUI, M. E.; NICOLINI, M. G.; RUIZ, R. A.; DODDS, P. A. Sowing date effects on grain yield components of different maize genotypes. Agronomy Journal, Madison, v. 87, n. 1, p. 29-33, Jan. 1995.

RAJCAN, I.; TOLLENAAR, M. Source:sink ratio and leaf senescence in maize. I. Dry matter accumulation and partitioning during grain filling. Field Crops Research, Amsterdam, v. 60, n. 2, p. 245-253, 1999a.

RAJCAN, I.; TOLLENAAR, M. Source-sink ratio and leaf senescence in maize. II. Nitrogen metabolism during grain filling. Field Crops Research, Amsterdam, v. 60, n. 2, p. $255-265,1999$ b.
RITCHIE, S. W.; HANWAY, J. J. How a corn plant develops. Ames : Iowa State University of Science and Technology, 1993. 26 p. (Special Report, 48).

RUSSEL, W. A. Genetic improvement of maize yields. Advances in Agronomy, San Diego, v. 46, n. 1, p. 245 298, 1991

SANGOI, L. An ideotype of maize for conditions of high temperature and low moisture. Ames : Iowa State University, 1996. 350 p. Ph.D. Thesis.

SANGOI, L.; ALMEIDA, M. L. de. Doses e épocas de aplicação de nitrogênio para a cultura do milho num solo com alto teor de matéria orgânica. Pesquisa Agropecuária Brasileira, Brasília, v. 29, n. 1, p. 13-24, jan. 1994

SANGOI, L.; SALVADOR, R. J. Effect of maize plant detasseling on grain yield, tolerance to high plant density and drought stress. Pesquisa Agropecuária Brasileira, Brasília, v. 33, n. 5, p. 677-684, maio 1998a

SANGOI, L.; SALVADOR, R. J. Influence of plant height and leaf number on maize production. Pesquisa Agropecuária Brasileira, Brasília, v. 33, n. 3, p. 297-306, mar. 1998b.

SOULE, J. D.; PIPER, J. K. Farming in nature's image Washington : Island, 1992. $330 \mathrm{p}$.

TEDESCO, M. J.; VOLKSVEISS, S. J.; BOHEN, H. Análise de solo, plantas e outros materiais. Porto Alegre : UFRGS-Faculdade deAgronomia, 1985. 188 p. (Boletim Técnico, 5).

TOLLENAAR, M. Physiological basis of genetic improvement of maize hybrids in Ontario from 1959 to 1988. Crop Science, Madison., v. 31, n. 1, p. 119-124, Jan. 1991.

TOLLENAAR, M.; AGUILERA, A.; NISSANKA, S. P. Grain yield is reduced more by weed interference in an old than in a new maize hybrid. Agronomy Journal, Madison, v. 89 , n. 2, p. 239-246, Mar. 1997

TOLLENAAR, M.; DAYNARD, T. B. Effect of source: sink ratio on dry matter accumulation and leaf senescence of maize. Canadian Journal of Plant Science, Ottawa, v. 62, n. 4 , p. $855-860$, Sept. 1982.

TOLLENAAR, M.; McCULLOUGH, D. E.; DWYER, L. M. Physiological basis of the genetic improvement of corn. In: SLAFER, G. A. (Ed.). Genetic improvement of field crops. New York : M. Dekker, 1994. p. 183-236.

WOLFE, D. H.; HENDERSON, D. W.; HSIAO, T. C.; ALVINO, A. Interative water and nitrogen effects on the senescence of maize. I. Leaf area duration, nitrogen distribution and yield. Agronomy Journal, Madison, v. 80, n. 4 , p. $859-864$, July 1988 